\title{
Removal of Cadmium and Cyanide from Aqueous Solutions through Electrodialysis
}

\author{
Luciano Marder, Guilherme O. Sulzbach, Andréa M. Bernardes and Jane Zoppas Ferreira* \\ LACOR, PPGEM, Universidade Federal do Rio Grande do Sul, Av. Osvaldo Aranha, 99/706, \\ 90035-190 Porto Alegre - RS, Brazil
}

\begin{abstract}
A descarga de efluentes contendo metais pesados e cianeto pelas indústrias de galvanoplastia é uma das maiores fontes de poluição dos recursos hídricos. O emprego da técnica de eletrodiálise para o tratamento de um efluente sintético contendo aproximadamente $0,0089 \mathrm{~mol} \mathrm{~L}^{-1}$ de cádmio e 0,081 mol L $\mathrm{L}^{-1}$ de cianeto foi estudado utilizando uma célula de eletrodiálise de cinco compartimentos. Os resultados demonstram que a remoção de cádmio e cianeto depende da densidade de corrente aplicada e é limitada pela precipitação de cádmio sobre a membrana catiônica.

The discharge of galvanic industry wastewaters containing heavy metals and cyanide is one of the largest sources of water pollution. The use of the electrodialysis technique for the treatment of a synthetic wastewater containing approximately $0.0089 \mathrm{~mol} \mathrm{~L}^{-1}$ cadmium and $0.081 \mathrm{~mol} \mathrm{~L}^{-1}$ cyanide was studied using a five-compartment electrodialysis cell. The results demonstrate that the removal of cadmium and cyanide depends on the applied current density and it is limited by the precipitation of cadmium on the cation-exchange membrane in the diluate central cell compartment.
\end{abstract}

Keywords: cadmium, cyanide, electrodialysis, wastewater

\section{Introduction}

The release of industrial wastewaters containing cadmium and cyanide to the environment is strictly controlled due to the toxic nature of these substances. To reduce the environmental impacts it is necessary to remove these substances from wastewater before its discharge in the environment. ${ }^{1}$ One of the largest cadmium and cyanide sources, which contributes largely to water pollution, are the electroplating industries that use cadmium cyanide baths. The main problems associated to this process, from the environmental point of view, are the deposition baths and rinsewaters discharges. The alkaline-chlorination process for cyanide destruction with further cadmium hydroxide precipitation is a common method employed for the treatment of the wastewaters characterized by the presence of these substances. However, chlorination of cyanides can result in highly toxic intermediates (cyanogen chlorides) and other toxic organo-chlorines that can be formed. These compounds together with residual chlorine create additional environmental problems. Metal precipitation can generate a large amount of cadmium hydroxide sludge classified as dangerous waste by the

*e-mail: cafjzf@ufrgs.br
Brazilian Regulation - NBR10004 ${ }^{2}$ and its appropriate disposition constitutes a serious environmental and economical problem for the involved industries. ${ }^{3-5}$

The development of more advanced technologies for wastewater treatment has increased in last years and new techniques have been suggested as promising possibilities, not only for the removal but also for the recovery of substances present in the wastewater. ${ }^{6-9}$ Among these new techniques, electrodialysis can be mentioned. ${ }^{10-13}$ Electrodialysis is a membrane separation process in which ionic species in solution are transported through ionexchange membranes, under the influence of an electric field from one solution to another. In an electrodialysis stack, as shown in Figure 1, cation-exchange and anionexchange membranes are alternately arranged in a filter press-like system to form diluted and concentrated flows between the membranes. The electrodes, disposed at the end of the stack, are in contact with an electrode rinse solution. The applied direct current electric field produces the transport of cations towards the cathode and anions towards the anode.

During this transport anions are able to permeate through the anion-exchange membrane, but are blocked by the cation-exchange membrane. The opposite occurs with cations. As a result, two different solutions are produced inside the stack: one more diluted (the diluate) 


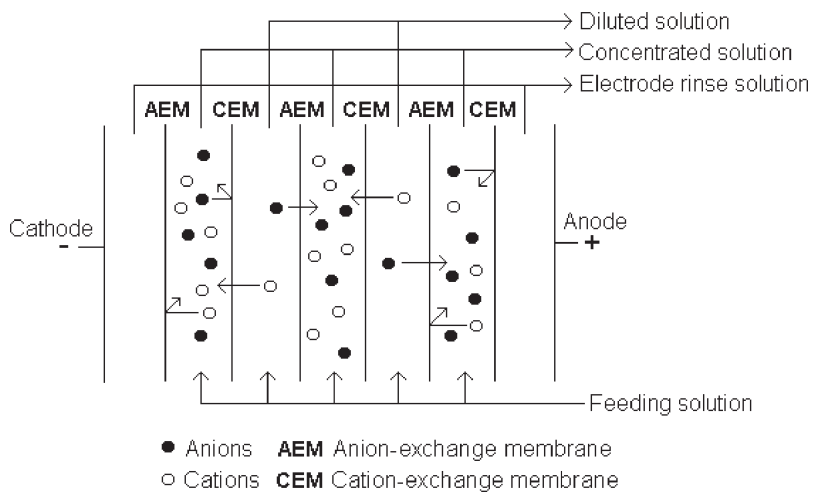

Figure 1. Electrodialysis technique principle.

and another more concentrated (the concentrate) than the feeding solution. ${ }^{14,15}$ Considering that this membrane separation technique is able to transform a concentrated solution in two other solutions, one more concentrated and another more diluted than the original solution (feeding solution), electrodialysis presents large application in what concerns the galvanic industries wastewater treatment, because it makes it possible to reuse the more diluted solution as rinsewater and the more concentrated solution in the deposition bath. ${ }^{16,17}$

The objective of this work was to verify the possibility of use of the electrodialysis technique to remove cadmium and cyanide from a synthetic wastewater containing approximately $0.0089 \mathrm{~mol} \mathrm{~L}^{-1}$ cadmium and $0.081 \mathrm{~mol} \mathrm{~L}^{-1}$ cyanide applying different current densities.

\section{Experimental}

\section{Electrodialysis cell and solutions}

The electrodialysis cell used in this work and represented in Figure 2 was composed of five compartments separated alternately by cation-exchange and anionexchange membranes. The cell was manufactured in transparent acrylic. The cation-exchange and anionexchange membranes used were NAFION 450 and SELEMION AMV, respectively. The effective membrane area was $16 \mathrm{~cm}^{2}$. The two outer compartments contain the working electrodes (platinum sheets) both with $16 \mathrm{~cm}^{2}$ effective area. The solutions in the three central compartments circulate independently while in the electrode compartments the same solution is circulated in closed circuit to avoid $\mathrm{pH}$ variations due to electrodes reactions. In each cell compartment $500 \mathrm{~mL}$ of solution circulate.

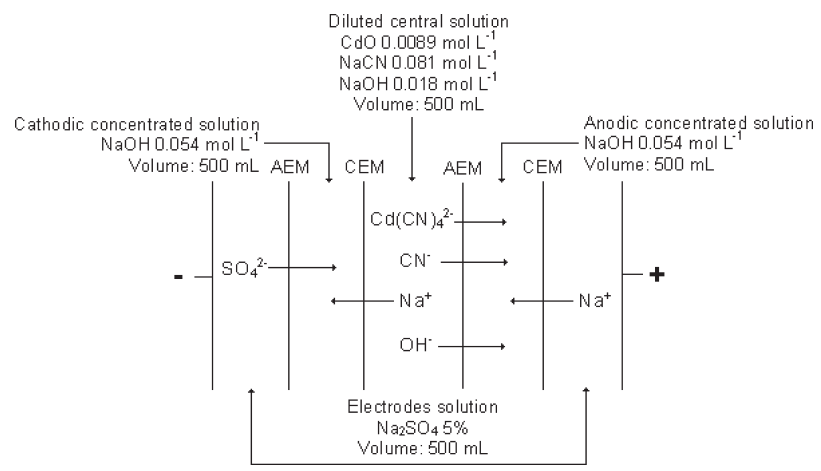

Figure 2. Five-compartment electrodialysis cell and the expected transport of the ionic species.

The solution to be treated $\left(0.0089 \mathrm{~mol} \mathrm{~L}^{-1} \mathrm{CdO}, 0.081\right.$ mol L ${ }^{-1} \mathrm{NaCN}$ and $0.018 \mathrm{~mol} \mathrm{~L}^{-1} \mathrm{NaOH}$ ) circulates in the diluate central cell compartment. A $0.054 \mathrm{~mol} \mathrm{~L}^{-1} \mathrm{NaOH}$ solution circulates in the anodic and cathodic concentrated cell compartments and a $\mathrm{Na}_{2} \mathrm{SO}_{4} 5 \%$ solution circulates in the electrodes compartments. The solutions were prepared with analytic grade reagents with distilled and deionized water. The current was applied through a $2.5 \mathrm{~A}-80 \mathrm{~V}$ power supply. The experiments were accomplished at least in duplicate at $25^{\circ} \mathrm{C}$. Cadmium concentration in the solutions was measured by Inductively Coupled Plasma Spectroscopy. Cyanide was measured by direct titration with an $\mathrm{AgNO}_{3}$ solution. ${ }^{18}$ The electrodialysis performance was evaluated in terms of percent extraction (pe) and current efficiency (ce), defined respectively by equations 1 and $2 .^{19,20}$

$p e=\frac{\left(C_{i}-C_{f}\right)}{C_{i}} \times 100$

where $C_{i}$ is the initial concentration of the ion and $C_{f}$ is the final concentration of the ion.

$c e=\frac{z F\left(m_{i}-m_{f}\right)}{n I \Delta t} \times 100$

where $z$ is the valency of the ion, $F$ is the Faraday constant ( $\left.96500 \mathrm{C} \mathrm{mol}^{-1}\right), m_{i}$ is the initial number of moles of the ion (moles), $m_{f}$ is the final number of moles of the ion (moles), $I$ is the electric current applied (A) and $\Delta t$ is the time interval (s) and $n$ is the number of membrane pairs.

At the experiments done at this work, the number of membrane pairs was considered equal to one, since the work solution is in contact just with one membrane pair (diluate central cell compartment). 


\section{Results and Discussion}

\section{Cadmium and cyanide transport through the ion-exchange membranes}

The experiments accomplished in the electrodialysis cell demonstrate that cadmium and cyanide are predominantly in anionic form, since they are transported only through the anion-exchange membrane. This behavior can be explained by the formation of negatively charged coordination complexes between cadmium and cyanide.

Cadmium and cyanide, in different proportions, lead up to the formation of different cadmium cyanide complexes in alkaline media. According to Prytz and Osterud, ${ }^{21}$ in the interval Cd:CN 1:4 and Cd:CN 1:20, the $\mathrm{Cd}(\mathrm{CN}){ }_{4}^{2-}$ complex should prevail. Flengas ${ }^{22}$ suggests that with excess of cyanide all the cadmium is complexed in the $\mathrm{Cd}(\mathrm{CN})_{4}{ }^{2-}$ form. Ortega and collaborators ${ }^{23}$ suggest that $\mathrm{Cd}(\mathrm{CN})_{4}{ }^{2-}$ is formed in great excess of cyanide to a solution $\mathrm{pH}$ higher than 10 . Koivula and co-workers ${ }^{24}$ demonstrates that for a $\mathrm{Cd}: \mathrm{CN}$ 1:10 system, 95\% of cadmium are under the $\mathrm{Cd}(\mathrm{CN})_{4}^{2-}$ form. In this work, the cadmium cyanide complexes speciation was obtained using the program HYDRA MEDUSA. ${ }^{25}$ Figure 3 shows that at the initial $\mathrm{pH}$ and cadmium and cyanide solution concentrations used in this work the predominant cadmium cyanide complex formed is $\mathrm{Cd}(\mathrm{CN})_{4}{ }^{2-}$, just like in cadmium-plating baths. The other ionic species present in the solutions are free cyanide $\left(\mathrm{CN}^{-}\right)$, hydroxide $\left(\mathrm{OH}^{-}\right)$and sodium $\left(\mathrm{Na}^{+}\right)$ions. ${ }^{17}$

In the electrodialysis cell, only sodium ions can pass through the cation-exchange membrane, whereas metal complexes, free cyanide and hydroxide ions are transported

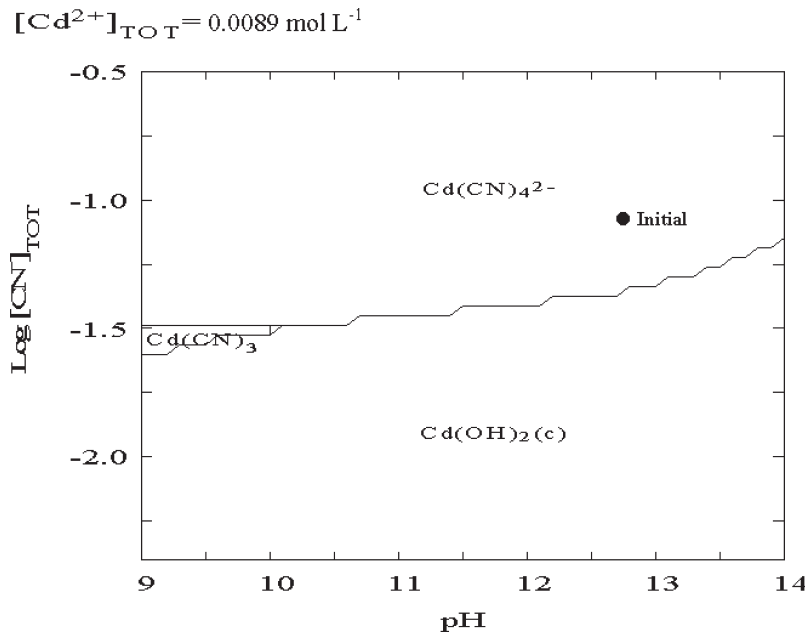

Figure 3. Speciation of cadmium and cyanide species as a function of the cyanide concentration and the solution $\mathrm{pH}\left(0.0089 \mathrm{~mol} \mathrm{~L}^{-1}\right.$ cadmium). through the anion-exchange membrane, as it can be observed in Figure 2.

Influence of the current density on the $\mathrm{Cd}(\mathrm{CN})_{4}^{2-}$ and $\mathrm{CN}^{-}$ ions removal

Experiments to establish the current density influence on the $\mathrm{Cd}(\mathrm{CN})_{4}{ }^{2-}$ and $\mathrm{CN}^{-}$ions removal were performed. Table 1 shows results obtained at 10,15 and $20 \mathrm{~mA} \mathrm{~cm}^{-2}$ current densities.

Table 1. $\mathrm{Cd}(\mathrm{CN})_{4}{ }^{2-}$ and $\mathrm{CN}^{-}$percent extraction and current efficiency for 10,15 and $20 \mathrm{~mA} \mathrm{~cm}{ }^{-2}$ current densities during $60 \mathrm{~min}-$ utes of electrodialysis.

\begin{tabular}{ccccc}
\hline i / $\mathrm{mA} \mathrm{cm}^{-2}$ & \multicolumn{2}{c}{ Percent extraction / \% } & \multicolumn{2}{c}{ Current efficiency / \% } \\
& $\mathrm{Cd}(\mathrm{CN})_{4}{ }^{2-}$ & $\mathrm{CN}^{-}$ & $\mathrm{Cd}(\mathrm{CN})_{4}{ }^{2-}$ & $\mathrm{CN}^{-}$ \\
\hline 10 & 11.6 & 18.2 & 15.4 & 65.8 \\
15 & 12.7 & 21.9 & 14.9 & 60.8 \\
20 & 15.8 & 31.4 & 10.9 & 55.9 \\
\hline
\end{tabular}

The results suggest that the percent extraction of the ionic species is higher when higher current densities are applied, even though the current efficiency is lower. It is clear that the lower current density resulted in better current utilization. The $\mathrm{CN}^{-}$ion removal is higher than the $\mathrm{Cd}(\mathrm{CN})_{4}{ }^{2-}$ ion. The cadmium cyanide complex is more voluminous than cyanide ion, what indicates that it is more difficult to transport larger ions through the anionexchange membrane.

\section{Cadmium compound precipitation on cation-exchange membrane}

Experiments accomplished with $20 \mathrm{~mA} \mathrm{~cm}^{-2}$ and during 240 minutes of electrodialysis result in $86 \% \mathrm{Cd}(\mathrm{CN})_{4}{ }^{2-}$ and $95 \% \mathrm{CN}^{-}$extraction, as it can be observed in Figure 4.

However a cadmium compound precipitation on the cation-exchange membrane disposed between the cathodic concentrate and the diluate central cell compartments was observed. Such precipitation is not observed up to $90 \mathrm{~min}$ of electrodialysis, where $23 \% \mathrm{Cd}(\mathrm{CN})_{4}{ }^{2-}$ and $43 \% \mathrm{CN}^{-}$ extraction occur. Figures $5 \mathrm{a}$ and $6 \mathrm{a}$ show micrographs obtained by SEM (Scanning Electron Microscopy) for a cation-exchange membrane before its use (new membrane) and for the cation-exchange membrane used up to 240 min of electrodialysis, respectively. Figures $5 \mathrm{~b}$ and $6 \mathrm{~b}$ show the corresponding membranes EDS (Energy Dispersion Spectroscopy) spectra, respectively.

From Figure $6 \mathrm{~b}$ it is clear that the precipitate corresponds to a compound containing cadmium. 


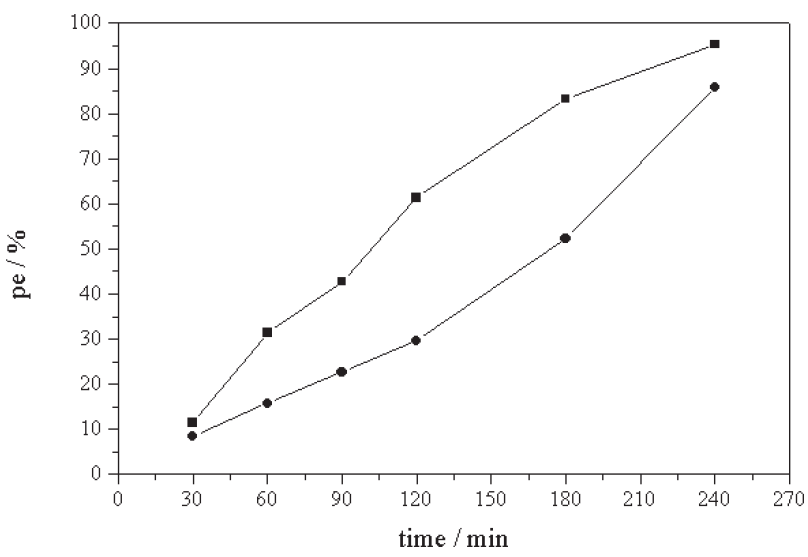

Figure 4. $\mathrm{Cd}(\mathrm{CN})_{4}{ }^{2-}$ and $\mathrm{CN}^{-}$percent extraction as a function of the electrodialysis time with a $20 \mathrm{~mA} \mathrm{~cm}{ }^{-2}$ current density. $(\bullet) \mathrm{Cd}(\mathrm{CN})_{4}{ }^{2-}$ (ם) $\mathrm{CN}^{-}$.

However, a more accurate analysis should be conducted to determine which cadmium compound is formed. This precipitation represents a drawback for the electrodialysis process since the precipitate formation on ion-exchange membranes can reduce the effective membrane area and consequently the process efficiency. Besides, it can cause irreversible membrane damages reducing its life cycle and increasing operational costs.

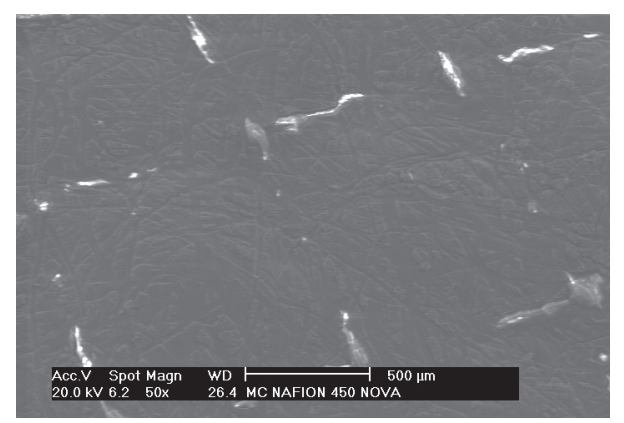

a

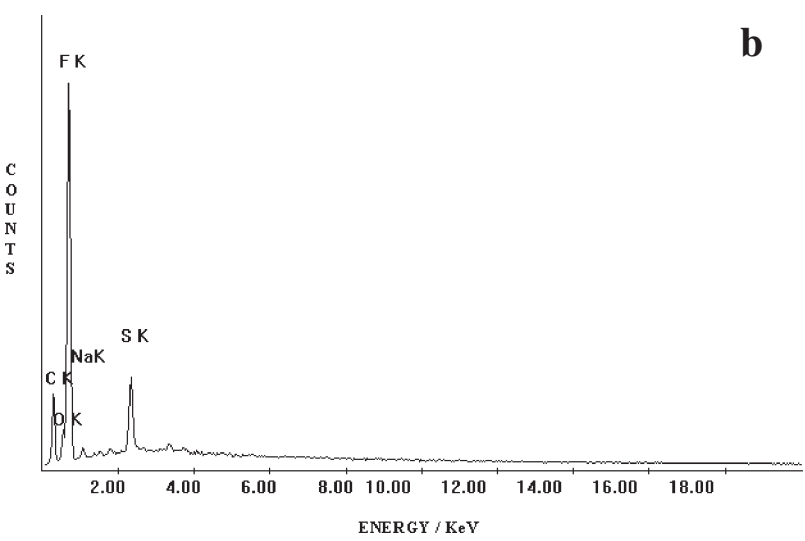

Figure 5. (a) New cation-exchange membrane (NAFION 450) micrograph and (b) respective EDS spectra.
It is well know in electrodialysis that the precipitation on ion-exchange membranes can be a consequence of operating above the limiting current density. In this case water dissociation in $\mathrm{H}^{+}$and $\mathrm{OH}^{-}$ions can occur, what might cause changes in the $\mathrm{pH}$ of the boundary layer formed in the membrane/solution interface, leading to a local change in the characteristics of the ionic species present in the solution. Insoluble compounds can be formed and then precipitate on the ion-exchange membrane.

Previous results have shown that with these membranes and these solutions there is a limiting current density at the cation-exchange membrane at approximately $25 \mathrm{~mA}$ $\mathrm{cm}^{-2} .{ }^{13,26}$ Since in this work $20 \mathrm{~mA} \mathrm{~cm}{ }^{-2}$ was applied during $240 \mathrm{~min}$ for the ions removal, it can be estimated that during this prolonged experimental interval, the system could reach the limiting current density.

Figure 7 demonstrates that if $\mathrm{pH}$ increases and cadmium and cyanide concentration decrease, insoluble $\mathrm{Cd}(\mathrm{OH})_{2}$ can be formed. $\mathrm{Cd}(\mathrm{OH})_{2}$ might then precipitate on the cation-exchange membrane.

By these considerations it can be estimated that the cadmium compound formed and precipitated on the membrane is $\mathrm{Cd}(\mathrm{OH})_{2}$. It is clear that accurate $\mathrm{pH}$ measurements should be available near the membrane/ solution interface to confirm these hypotheses.

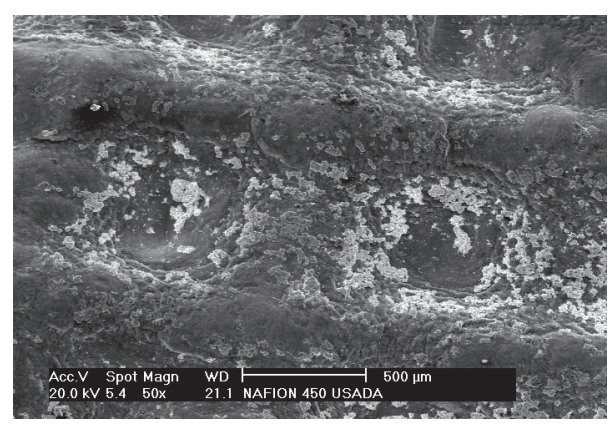

a

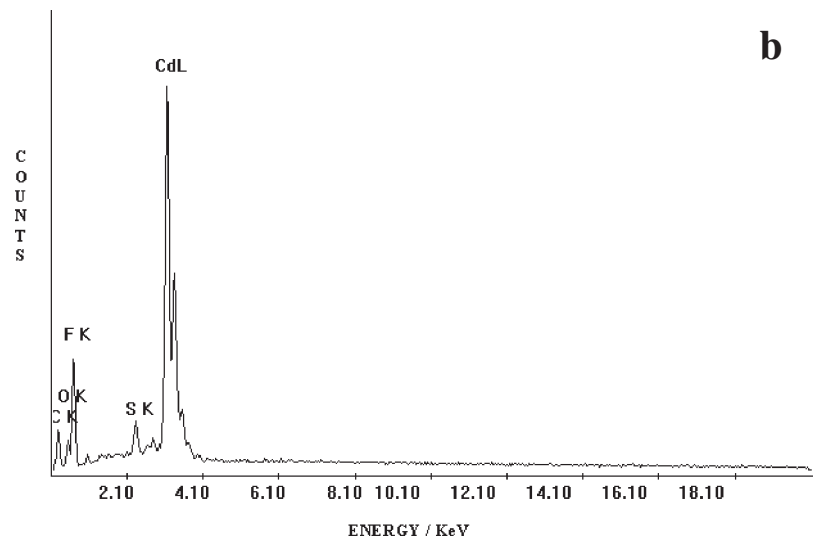

Figure 6. (a) Used cation-exchange membrane (NAFION 450) micrograph and (b) respective EDS spectra. 


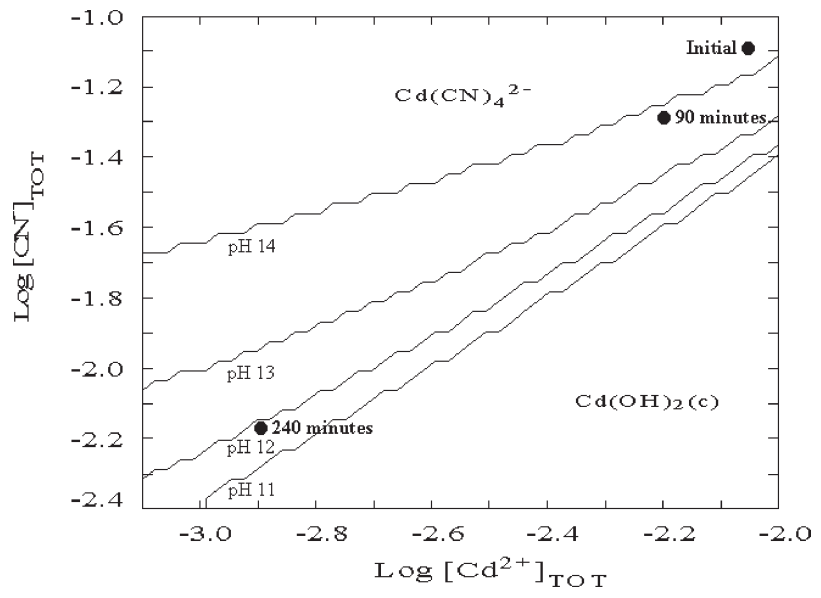

Figure 7. Speciation of cadmium and cyanide ionic species as a function of cadmium and cyanide concentrations and the solution $\mathrm{pH}$.

Behavior of the $\mathrm{pH}$ and the conductivity of the solutions and the cell voltage

During the electrodialysis process with a $20 \mathrm{~mA} \mathrm{~cm}{ }^{-2}$ current density the cell voltage (measured between the two platinum electrodes), the $\mathrm{pH}$ and the conductivity of the solutions (measured directly in the solutions reservoirs) were also determined. The determined $\mathrm{pH}$ value represents the bulk $\mathrm{pH}$ of the solution and not necessarily the $\mathrm{pH}$ in the membrane/solution interface. This behavior can be observed in Figures 8, 9 and 10.

Figure 8 shows that there is a decrease on the bulk $\mathrm{pH}$ at the diluate central cell compartment. This decrease could be associated to the $\mathrm{OH}^{-}$consumption that occurs during the formation and precipitation of $\mathrm{Cd}(\mathrm{OH})_{2}$.

The conductivity decrease in the diluate central cell compartment indicates the $\mathrm{Cd}(\mathrm{CN})_{4}^{2-}, \mathrm{CN}^{-}, \mathrm{Na}^{+}$and $\mathrm{OH}$

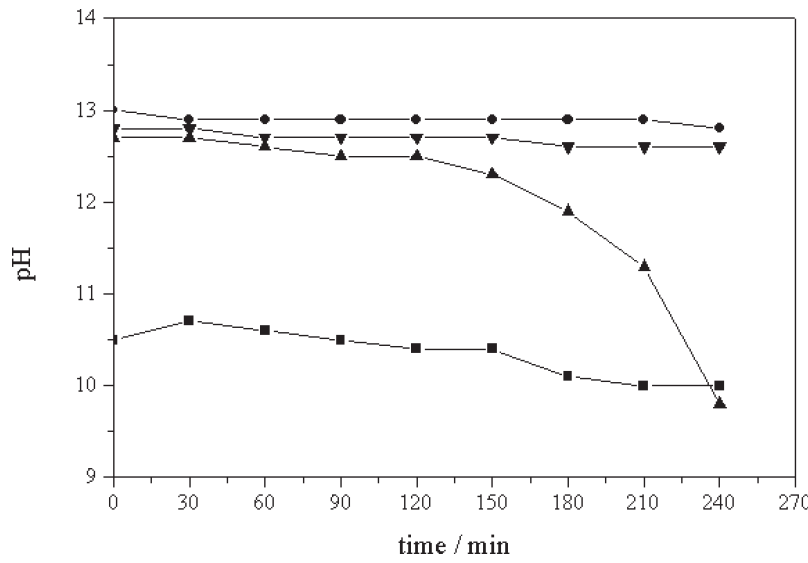

Figure 8. Behavior of the solutions $\mathrm{pH}$ in the electrodialysis cell compartments during 240 minutes of electrodialysis with $20 \mathrm{~mA}$ $\mathrm{cm}^{-2}$ current density. ( $\left.\boldsymbol{\square}\right)$ Electrodes $(\boldsymbol{\cup})$ Anodic $(\boldsymbol{\Delta})$ Central $(\boldsymbol{\nabla})$ Cathodic.

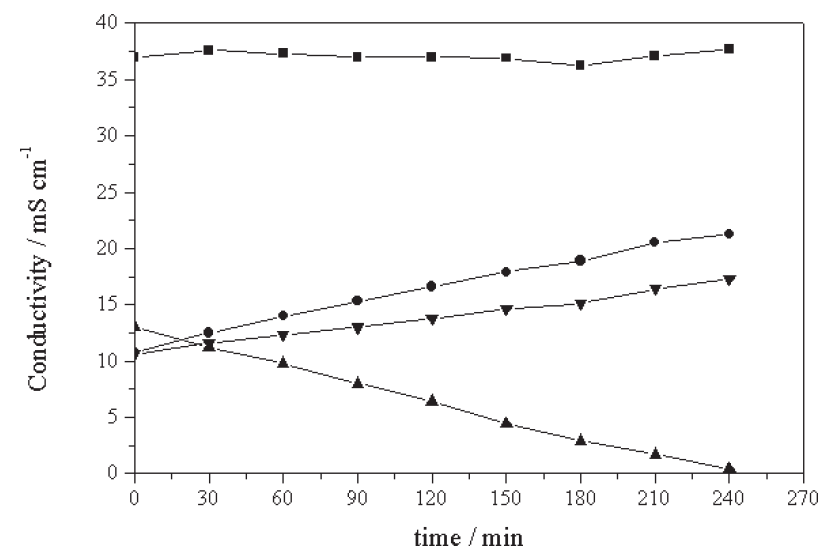

Figure 9. Behavior of the solutions conductivity in the electrodialysis cell compartments during 240 minutes of electrodialysis with 20

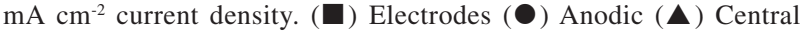
$(\boldsymbol{\nabla})$ Cathodic.

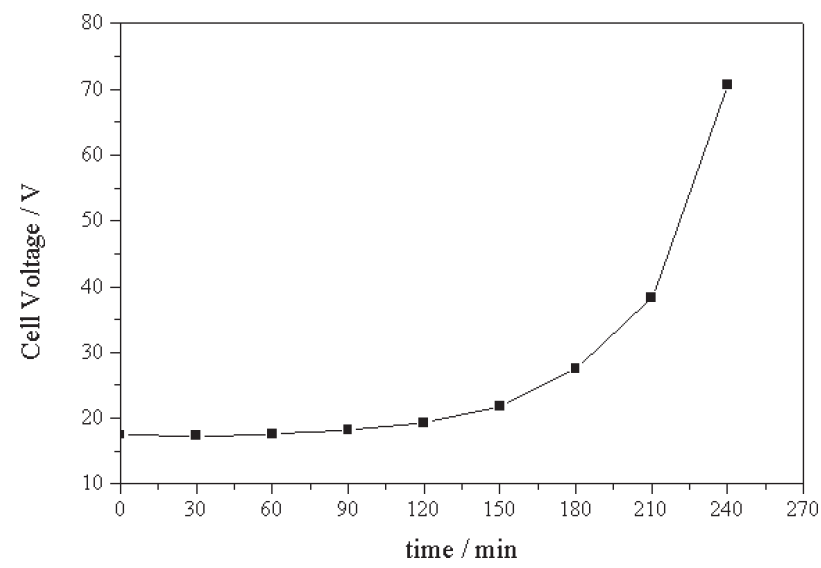

Figure 10. Behavior of the cell voltage during 240 minutes of

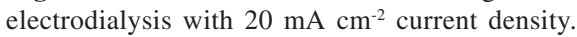

ions removal (Figure 9). The conductivity increase in the anodic concentrate cell compartment can be attributed to the $\mathrm{Na}^{+}$transport from the electrodes compartment and to the $\mathrm{Cd}(\mathrm{CN})_{4}^{2-}, \mathrm{CN}^{-}$and $\mathrm{OH}^{-}$transport from the diluate central cell compartment. The conductivity increase in the cathodic concentrate cell compartment can be attributed to the $\mathrm{SO}_{4}^{2-}$ transport from the electrodes compartment and to the $\mathrm{Na}^{+}$transport from the diluate central compartment.

The cell voltage increase can be attributed to the decrease in the conductivity of the diluate central cell compartment solution as a consequence of the ionic species removal increasing the solution electrical resistance (Figure 10). Besides, when Figures 8 and 10 are compared, it can be seen that when bulk pH decreases in the diluate central cell compartment the cell voltage increases. This behavior could be all related to a limiting current density at the cation-exchange membrane. 


\section{Conclusion}

The results presented here demonstrate that cadmium and cyanide transport occurs only through the anionexchange membrane towards the anode, indicating that the ionic species are negatively charged. Cadmium and cyanide percent extraction and current efficiency depend on the applied current density and the total removal of the ionic species is limited by a cadmium compound precipitation on the cation-exchange membrane of the diluate central cell compartment. More accurate experiments should be done to try to avoid the cadmium compound precipitation and to achieve higher ionic species removal. One alternative is the treatment of solutions by electrodialysis in a continuous way or with successive changes of solution in the diluate central cell compartment.

\section{Acknowledgements}

The authors wish to thank CAPES and FAPERGS for financial support.

\section{References}

1. Butter, T. J.; Evison, L. M.; Hancock, I. C.; Holland, F. S.; Matis, K. A.; Philipson, A.; Sheikh A. I.; Zouboulis, A. I.; Water Res. 1998, 32, 400.

2. BRAZIL, ABNT; Waste Classification (Classificação de Resíduos): NBR 10004, 1987, in Portuguese.

3. Hartinger, L.; Handbook of Effluent Treatment and Recycling for the Metal Finishing Industry, $2^{\text {nd }}$. ed., Finishing Publications: UK, 1994.

4. Ho, S. P.; Wang, Y. Y.; Wan, C. C.; Water Res. 1990, 24, 1317.

5. Ogutveren, U. B.; Toru, E.; Koparal, S.; Water Res. 1999, 33, 1851.

6. Janssen, L. J. J.; Koene, L.; Chem. Eng. J. 2002, 85, 137.

7. Riley, C. T.; Semmens, M. J.; Plat. Surf. Finish. 1994, 46.

8. Monser, L.; Adhom, N.; Sep. Purif. Technol. 2002, 26, 137.
9. Goel, M.; Agrawal, V.; Kulkarni, A. K.; Cramer, S. M.; Gill, W. N.; J. Membr. Sci. 1998, 141, 245.

10. Bernardes, A. M.; Dalla Costa, R. F.; Fallavena, V. L. V.; Rodrigues, M. A. S.; Trevisan, M. D.; Zoppas Ferreira, J.; Metal Finishing 2000, 98, 52.

11. Klishenko, R.; Kornilovich, B.; Chebotaryova, R.; Linkov, V.; Desalination 1999, 126, 159.

12. Sapari, N.; Idris, A.; Hamid, N. H. A.; Desalination 1996, 106, 419.

13. Marder, L.; MSc. Dissertation. Universidade Federal do Rio Grande do Sul, Brazil, 2002, in Portuguese.

14. Rowe, D. R.; Abdel-Magid, I. M.; Handbook of Wastewater Reclamation and Reuse, CRC Press: New York, 1995.

15. Genders, J. D.; Weinberg, N. L.; Electrochemistry for a Cleaner Environment, Electrosynthesis Company: New York, 1992.

16. Audinos, R.; Chem. Eng. Sci. 1983, 38, 431.

17. Chiapello, J. M.; Gal, J. Y.; J. Membr. Sci. 1992, 68, 283.

18. Blum, G., Hogaboom, G. B.; Principles of electroplating and electroforming, $3^{\text {rd }}$ ed., MCGraw-Hill: New York, 1949.

19. Gain, E.; Laborie, S.; Viers, Ph.; Rakib, M.; Hartmann, D.; Durand, G.; Desalination 2002, 149, 337.

20. Tzanetakis, M.; Taama, W. M.; Scott, K.; Jachuck, R. J. J.; Slade, R. S.; Varcoe, J.; Sep. Purif. Technol. 2003, 30, 113.

21. Prytz, M.; Osterud, TH.; Acta Chem. Scand. 1952, 6, 1534.

22. Flengas, S. N.; Trans. Faraday Soc. 1955, 52, 62.

23. Ortega, E.; Pérez-Herranz, V.; Guiñón, J. L.; García-Antón, J.; Proceedings of the International Water Conference, Porto, Portugal, 2001.

24. Koivula, R.; Lehto, J.; Pajo, L.; Gale, T.; Leinonen, H.; Hydrometallurgy 2000, 56, 93.

25. Puigdomenech, I.; HYDRA MEDUSA; Make Equilibrium Diagrams Using Sophisticated Algorithms; Royal Institute of Technology: Stockholm, Sweden, 2001.

26. Marder, L.; Bernardes, A. M.; Zoppas Ferreira, J.; J. Appl. Electrochem., submitted.

Received: February 4, 2003 Published on the web: August 8, 2003 